\title{
IFAS Community Development: Defining Local Power Structures to Facilitate Leadership and Community Development 1
}

\section{Mark A. Brennan ${ }^{2}$}

This paper is part of a series of discussions on community development. This series includes specialized papers on leadership development, civic engagement, community action, and other topics important to the development of community.

\section{Introduction}

The development of effective local leadership and community development is often contingent upon whether you are operating in collaboration or conflict with local power structures. An understanding of local power structures is essential to identifying residents to serve as leaders who can take on an active role in local development efforts. To begin this process, it is first important to understand the types of power that might exist within the community. With an understanding of the types of power and their capacity for shaping local decision making, community residents can plan accordingly to maximize their efforts.

\section{Types of Power}

When thinking about the types of power and their role in shaping community development, it is important to note the conditions in which power can be controlled, and at times, monopolized. In assessing local power, the agendas of those possessing or seeking power must be considered. In such cases power can be sought for personal advancement or for more widespread conditions benefiting the community. Such motivations frame the presentation of power and possible response by the community.

Many different forms of local power exist. Boulding (1989) in Three Faces of Power, identifies three forms of power:

- Destructive power refers to the capacity to destroy something or someone. Most often it is used to enforce some kind of threat or sanction that has been ignored. Included are killing or destroying things with weapons, but also the destruction of things; bulldozers, developments, furnaces, or chain saws can be part of the process

1. This document is FCS9240, one of a series of the Family Youth and Community Sciences Department, Florida Cooperative Extension Service, Institute of Food and Agricultural Sciences, University of Florida. Original publication date: March 20, 2006. Visit the EDIS Web Site at http://edis.ifas.ufl.edu

2. M. A. Brennan, assistant professor, Department of Family, Youth and Community Sciences, Cooperative Extension Service, Institute of Food and Agricultural Sciences, University of Florida, Gainesville, FL, 32611.

The Institute of Food and Agricultural Sciences (IFAS) is an Equal Opportunity Institution authorized to provide research, educational information and other services only to individuals and institutions that function with non-discrimination with respect to race, creed, color, religion, age, disability, sex, sexual orientation, marital status, national origin, political opinions or affiliations. U.S. Department of Agriculture, Cooperative Extension Service, University of Florida, IFAS, Florida A. \& M. University Cooperative Extension Program, and Boards of County Commissioners Cooperating. Larry Arrington, Dean 
- Economic (productive) power reflects the ability to obtain something wanted by means of exchange. Following this reasoning, the more that an individual has to give in exchange (money, tangible items, labor, etc.), the more power they have. Economic power can be acquired temporarily by taking things away from others, but ultimately individuals need to be able to produce more money or resources to sustain their power.

- Integrative power refers to the capacity to get people to act out of respect, care, or love. The role of integrative power in maintaining social structures is both the most important and the least recognized or understood.

Finally, in addition to the above forms of power is knowledge power (Hyman, 2001). This power is based in the accumulation of knowledge, skills, and experiences that give people an advantage in accumulating power.

Related to the above faces of power, we can identify five types of power relationships: threat, authority, influence, manipulation, and force (Bachrach and Baratz, 1970). These are central to our understanding of the dynamics of power in the decision making process at the local level. Threat power is a rational concept that is based on the relationship between two or more parties. It is based on compliance with requests or orders by one group as a result of pressure and deprivations by another. This concept is based on reason in that the second party must perceive the threats presented to them and view them as valid considerations. While threat power may work for a short period of time, it tends to arouse resentment and consequently less success, so that long-term implications for sustaining this type of power are limited.

- Authority can be similar to threat power, when it is based not on the immediate threat to deprive individuals of something, but on the perceived ability to do so. Authority is found in a belief that those in power maintain legitimacy and a right to that power. This authority can take many forms. Some forms rest on a belief in the legitimacy and legality of laws, rules, and the right of those in power to issue commands. More traditional authority is based on an established belief in the tradition, sanctity, and legitimacy of those exercising authority under them. Similarly, some people are charismatic and their authority centers on a devotion to the specific and extraordinary character of an individual person, and of the orders given by this person. Finally, authority can rest on an attachment to a set of values or belief systems that is the object of intense commitment.

- Influence involves a belief that a person making a request deserves to be or needs to be obeyed. Obedience and influence may result from who the person is in society (status or respect) or from agreement with the request itself (as a result of discussion and debate). One person has influence over another to the extent that the first causes the second to change his course of action.

- Manipulation is an invisible power.

Manipulation is characterized by doing what another wants without being aware of it. In this situation there is a conflict of values in that one person would not take the action without being manipulated. However, there is no relationship that leads the complier to be aware of the request or to decide to obey.

Finally, force is obvious power. Force involves the application of severe sanctions threatened in a power relationship. In this setting, action is taken against a persons will. The key to the power relationships is who chooses the ultimate action.

\section{Conclusion and Implications for Community Development}

While most visions of power focus on ruling elites and groups, substantial power also exists in the individual. The power of the individual and the coordinated power of the groupings of individuals can be recognized and used for fostering change in the community. By recognizing local power, it can be used to help community action and local leadership capacities to emerge. Ultimately, power structures exist in all communities. In many communities the distribution of power can be widespread and seen in diverse parts of the community. Maximizing these forms of local power necessitates strong local leadership and organized community capacity. 


\section{References and Useful Reading}

Bachrach, P. and M. Baratz 1970. Poverty:

Theory and Practice. New York, NY: Oxford

University Press.

Boulding, K. 1989. The Three Faces of Power. Thousand Oaks, CA: Sage Publications.

Hyman, D., J. McKnight, and F. Higdon. 2001. Doing Democracy: Conflict and Consensus Strategies for Citizens, Organizations, and Communities. New York, NY: Erudition Press. 